\title{
Diagnostics of pikas (Lagomorpha, Ochotonidae, Ochotona) from the Putorana Plateau, Eastern Siberia
}

\section{Andrey A. Lissovsky \& Elena V. Lissovskaya}

\begin{abstract}
Body and skull measurements, frontopariteal suture, palatal opening, pelage coloration, and alarm calls in two sympatric races of the pikas from the Putorana Plateau were investigated. These data confirms that characters distinguishing these two races are of the species level. A key characters to distinguished these races are discussed.
\end{abstract}

KEY WORDS: Ochotona, taxonomy, morphology, acoustic signals, Putorana Plateau.

Andrey A. Lissovsky [andlis@zmmu.msu.ru], Zoological Museum of the Moscow State University, Bolshaya Nikitskaya 6, Moscow 103009 Russia; Elena V. Lissovskaya, Hematological Scientific Center RAMN, Novozykovsky proezd 4a, Moscow 125167 Russia.

\section{Диагностика пищух (Lagomorpha, Ochotonidae, Ochotona) плато Путорана, Восточная Сибирь}

\begin{abstract}
А.А. Лисовский, Е.В. Лисовская
РЕЗЮМЕ. Исследованы размеры черепа и тела, строение венечного шва и небного отверстия черепа, окраска шерсти, структура предупреждающих об опасности сигналов пищух плато Путорана. Подтверждается видовой уровень различий между двумя обитающими здесь формами. Приводятся определительные признаки.
\end{abstract}

КЛЮЧЕВЫЕ СЛОВА: Ochotona, таксономия, морфология, звуковые сигналы, Плато Путорана.

\section{Introduction}

The Putorana Plateau, situated to the south of the Taimyr Peninsula, Eastern Siberia in the northern Russia, has been traditionally referred to the geographic range of the northern pika, Ochotona hyperborea (Pallas 1811) (Ognev, 1940; Sokolov et al., 1994). However, recently there two sympatric races of the pikas, differing in body and skull measurements, pelage coloration, alarm calls structure, and karyologic characters were detected (Formozov, 1991; Formozovet al., 1999). One race, having larger size and diploid number of 42 chromosomes, was tentatively assigned to the alpine, or Altai pika, Ochotona alpina (Pallas, 1773) (Formozov et al., 1999). Our work presents results of the future investigation of the characters distinguishing these two races. Based on newly collected materials, we discuss the utility of all reliable characters to distinguish these sympatric races of pikas, both in the field and in the museum collections.

\section{Materials and methods}

The pikas were collected between June 4 and August 6, 1996, in the valley of the Lake Kutaramakan (the State Putorana Zapovednik), Taimyr Autonomous Region, Russia. An additional excursion was performed in the Noril'sk Mountains (the Zub Mountain), vicinity of the Noril'sk City in
Taimyr Peninsula. Altogether a sample of 60 complete skulls was investigated. These specimens come from seven different sites of the Putorana Plateau (Glubokoe Lake, Kutaramakan Lake, Lama Lake, Keta Lake, Khantai Lake, Sebyaki Lake, and Mikchanda River) and housed in the collections of the Zoological Museum, Moscow State University in Moscow (abbreviated ZMMU), of the Institute of Systematics and Ecology of the Animals, Siberian Branch of the Russian Academy of Sciences in Novosibirsk (ISEA), and of the Zoological Institute, Russian Academy of Sciences in St.-Petersburg (ZIN).

The palatal opening and frontoparietal suture were studied in a sample of 34 skulls, personally collected by the authors in the Putorana Plateau. All discovered characters were checked on the museum specimens; among latter only specimens having both skull and skin, with linear body measurements and weight indicated on the label, were considered.

Only adult wintered specimens were investigated. The individual age was determined by the state of development of the crests for masticatory muscles attachment in the dentary (Khmelevskaya, 1961). In comparison purposes we investigated a sample of 320 skulls of northern pika and 250 skulls of Altai pika, all coming from areas outside the Putorana Plateau.

The body measurements were taken from a sample of 39 specimens, personally collected by the authors in the Putorana Plateau.

The acoustic signals were recorded by the portable tape recorder 'Casio' TP-6 and microphone LOMO UM 51-01U1.1. The alarm calls of the Putorana pikas were analyzed on the basis of signal registration in 102 specimens, 54 of northern pika and 48 of Altai pika. The acoustic signals of the Altai pikas from the Altai-Sayany population were recorded by us 
Table 1. Measurements (in mm) of the body and the skull in the Putorana pikas.

\begin{tabular}{|l|c|c|c|c|c|c|c|c|c|c|}
\hline \multirow{2}{*}{ Measurements } & \multicolumn{4}{|c|}{ Altai pika } & \multicolumn{5}{c|}{ Northern pika } \\
\cline { 2 - 12 } & $\begin{array}{l}\text { Sample } \\
\text { size }\end{array}$ & Average & Minimum & Maximum & $\begin{array}{c}\text { Standard } \\
\text { deviation }\end{array}$ & $\begin{array}{c}\text { Sample } \\
\text { size }\end{array}$ & Average & Minimum & Maximum & $\begin{array}{c}\text { Standard } \\
\text { deviation }\end{array}$ \\
\hline Condylobasal length & 39 & 39.63 & 37.3 & 42.9 & 1.30 & 27 & 35.09 & 33.5 & 36.7 & 0.84 \\
\hline Length of nasales & 38 & 12.76 & 11.5 & 13.8 & 0.51 & 29 & 11.50 & 10.3 & 12.7 & 0.63 \\
\hline $\begin{array}{l}\text { Interorbital } \\
\text { constriction }\end{array}$ & 39 & 5.02 & 4.4 & 5.8 & 0.35 & 30 & 4.86 & 4.4 & 5.5 & 0.28 \\
\hline Zygomatic breadth & 37 & 20.44 & 18.3 & 21.5 & 0.78 & 30 & 19.02 & 17.8 & 20.1 & 0.83 \\
\hline Diastemal length & 39 & 8.56 & 7.5 & 9.9 & 0.60 & 30 & 7.15 & 6.0 & 8.8 & 0.72 \\
\hline $\begin{array}{l}\text { Alveolar length of } \\
\text { maxillary toothrow }\end{array}$ & 39 & 7.96 & 7.5 & 8.6 & 0.26 & 30 & 7.35 & 6.8 & 8.2 & 0.32 \\
\hline Skull height & 38 & 14.26 & 13.4 & 16.1 & 0.54 & 27 & 13.15 & 11.7 & 14.4 & 0.67 \\
\hline $\begin{array}{l}\text { Alveolar length of } \\
\text { mandibular toothrow }\end{array}$ & 37 & 7.35 & 6.5 & 8.1 & 0.38 & 27 & 6.73 & 6.1 & 7.9 & 0.42 \\
\hline Body mass, in g & 20 & 141.05 & 113.00 & 171.00 & 17.03 & 15 & 86.40 & 52.00 & 102.00 & 15.32 \\
\hline Body length & 31 & 173.48 & 158.00 & 190.00 & 7.97 & 25 & 148.64 & 132.00 & 165.00 & 9.18 \\
\hline Foot length & 31 & 27.37 & 25.00 & 30.00 & 1.34 & 25 & 22.48 & 21.00 & 25.00 & 1.09 \\
\hline Ear length & 30 & 19.57 & 16.00 & 24.00 & 1.94 & 26 & 15.88 & 13.00 & 20.00 & 1.42 \\
\hline
\end{tabular}

in the June 1997 and May 1999 in the central part of the Zapadnyi Sayan Range (Olenya River). The sound records were analyzed with the sonograph Avisoft-SASLab Light for Windows, version 3.0.

The pikas were shot by a smooth-bore gun of the 12 calibre or catch by traps $\mathrm{N} 0$. When possibly, the voice of animal to be collected was recorded. The sound signal was attributed to the animal collected only if the latter was still visible during all time between sound recording and shooting. Altogether, 12 northern pikas and 12 Altai pikas were collected with the acoustic signals recorded.

All statistic calculations were performed using the Statistica for Windows, version 5 software. Data on the minimal and maximal values, the mean value \pm standard error, standard deviation (s), sample size (n) for variables investigated are presented in the text.

\section{Results}

As was envisaged earlier, the pikas from the Putorana Plateau are falling into two discrete sympatric races. For the descriptive purposes, we shall name a race with diploid number of 42 chromosomes (Formozov et al., 1999) the Putorana Altai pika, and another race, having 40 chromosomes (Formozovet al., 1999), the Putorana northern pika. Below we shall discuss the reliability of some characters investigated for separation of these two races.

Pelage coloration. Differences between two pikas races on the Putorana Plateau were supposed earlier (Formozov, 1991). Our investigation is in accordance with this supposition. All pikas from the Putoran Plateau, collected or watched by authors, or housed in the museum collections, could be referred to one from two colored races. Differences in the coloration are so con- spicuous, that these races could be easily diagnosed in the field using a field glass.

In the summer pelage the Putorana Altai pika has back ochraceous-red and a dark blurred band on the back and nape formed by the hairs with black tips. The sides and belly are conspicuous ochraceous-red. There are small chestnut-red spots on the neck sides, which are poorly distinguishable on the common red background. The foots are dark-brown. The ears are fringed with a narrow light stripe.

In the winter the Putorana Altai pika changes the red coloration into the yellow-brown, or yellow-gray. The principal color is produced by the graphite-gray undercoat visible through the long hairs. On the gray background the chestnut-red spots on the neck sides are well emphasized.

In the summer pelage the Putorana northern pika has a back ochraceous-brown. The two colored hairs with dark base and tip and ochraceous middle make up a dense stroked pattern. On the sides the hairs lack black tips. The belly is gray, often with a sandy-yellow tinge. There are two ochraceous spots on the neck sides. There is a dark path on the nape and top of the head. The foots are light-gray. The ears are fringed with a narrow white stripe. The vibrissae are black.

In the winter coloration of the Putorana northern pika the gray-brown tinges are predominate. The fur around ears is gray.

Size variation. The size variation of the body and skull in the Putorana pikas is summarized up in the Table 1. The size differences between the two races of Putorana pikas discussed are statistically reliable for all measurements involved, except the interorbital breadth (Student' criterion, $t<0.05$ ). 


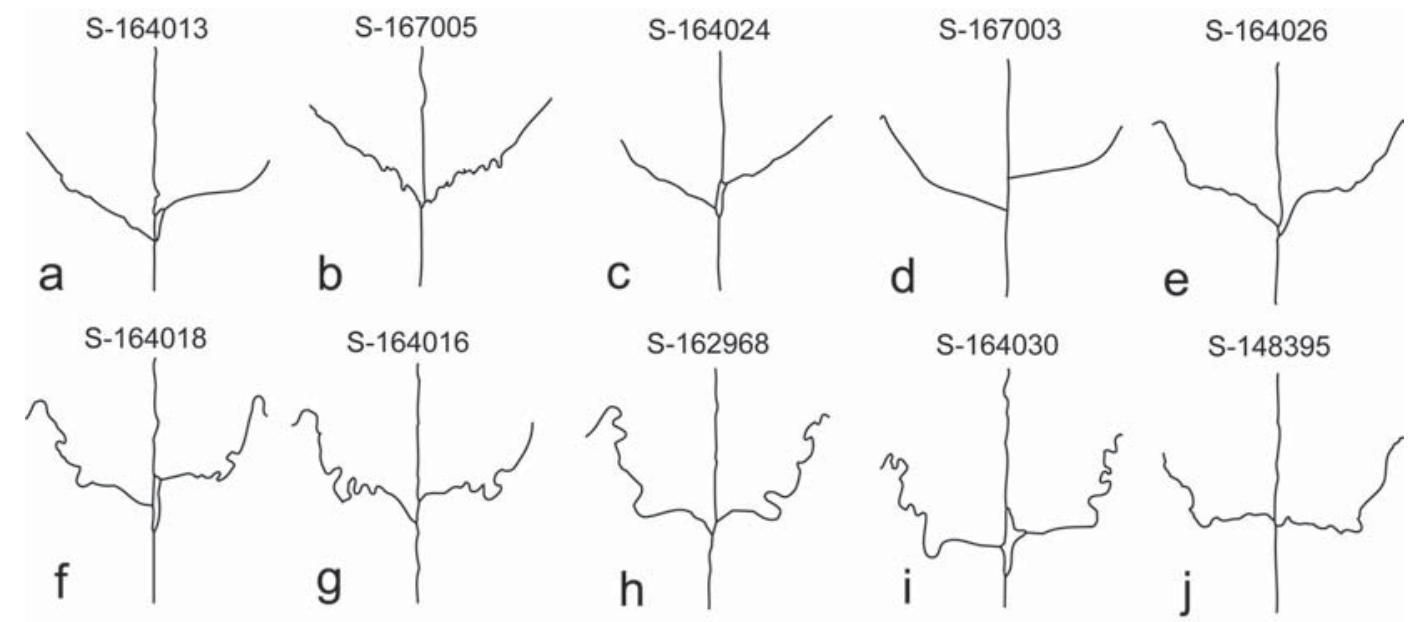

Figure 1. THE SHAPE OF THE FRONTOPARITEAL SUTURE IN THE PUTORANA PIKAS (a-e — northern pika, $\mathrm{f}-\mathrm{j}$ Altai pika). The ZMMU collection numbers are indicated.

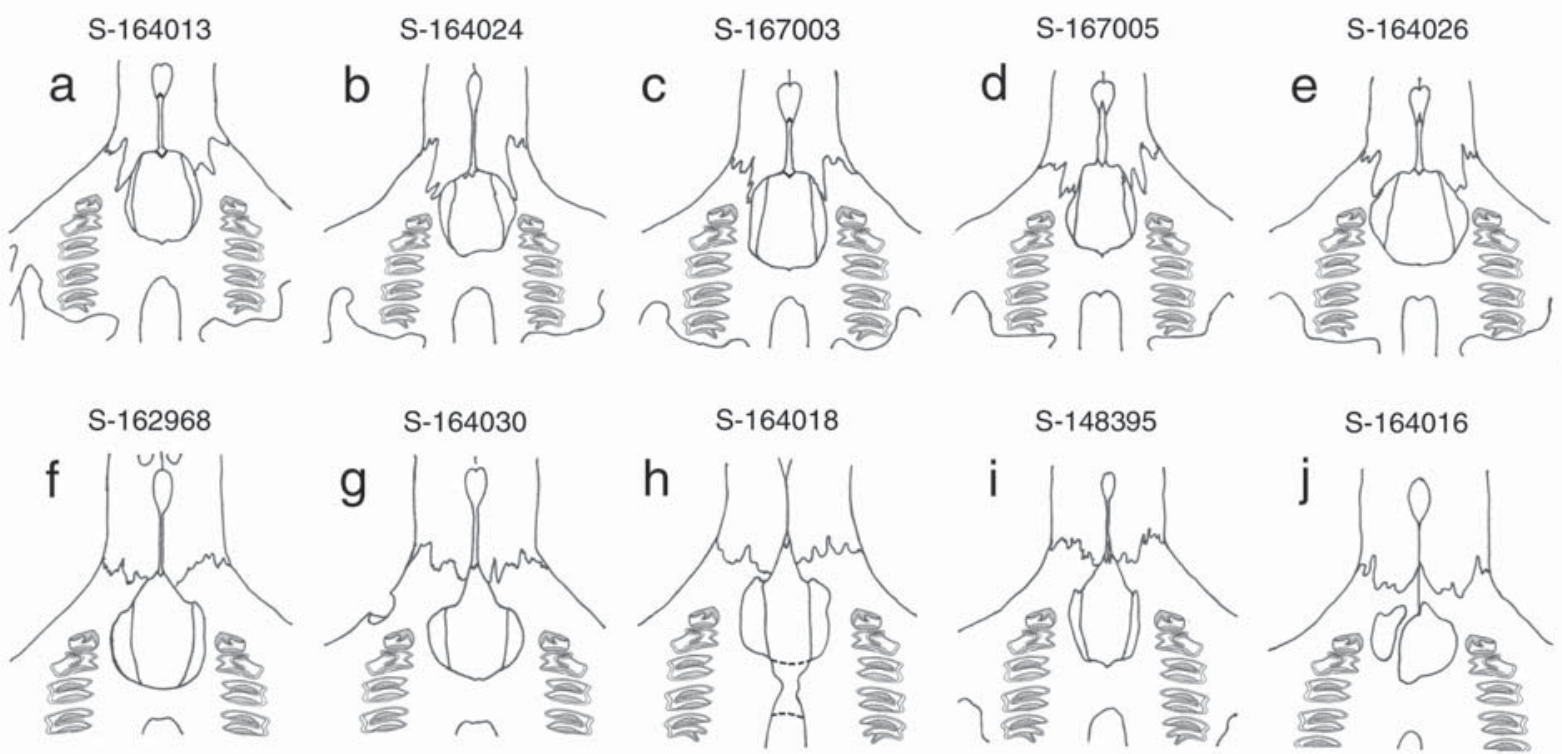

Figure 2. THE SHAPE OF THE PALATAL OPENING IN THE PUTORANA PIKAS (a-e - northern pika, $\mathrm{f}-\mathrm{j}$ - Altai pika). The ZMMU collection numbers are indicated.

Frontoparietal suture. For the Putorana Altai pika a U-shaped (trough-shaped) frontopariteal suture is characteristic (Fig. 1), with an uneven suture line. In the Putorana northern pika the frontals jut into the parietals, giving to the frontopariteal suture a V-shaped appearance; the suture line is more or less even. Unfortunately, this character is applicable to separation skulls of only adult animals, because a non-ossifying connective tissue membrane at the junction of these bones does not allow to detect the adult morphology. We should emphasize, that the noted differences in the frontopariteal suture are applicable only for distinguishing of the two races within the Putorana Plateau. Outside this region this charac- ter is more variable and both states can be found in both species, the northern and Altai pikas.

Palatal opening. In the Putorana northern pika the palatal opening is a regular trapezoid or rectangular outline. Its lateral edges are rounded, without any projections. The premaxillae form a part of the bony bridge, separating of the incisive and palatal foramina, visible in the ventral view. The premaxillae also form a pair of flat jags, embracing the anterior margin of the palatal foramen from lateral sides (Fig. 2).

In the Putorana Altai pika the palatal opening is of pear-shaped or irregular triangular-shaped because of protruding into the opening of the lateral "wings", formed 


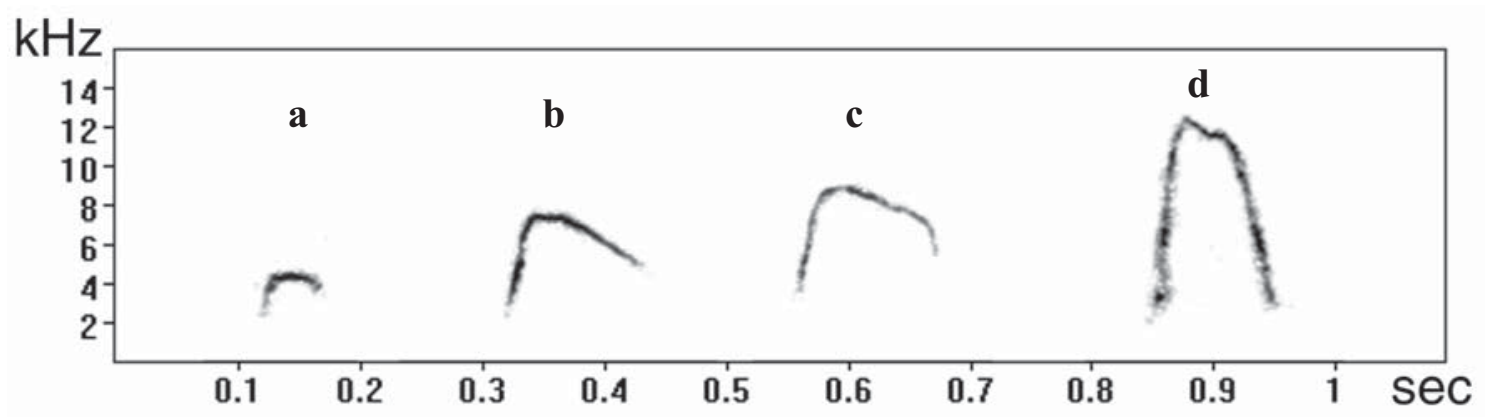

Figure 3. ALARM CALLS OF THE NORTHERN (a) AND ALTAI (b, c) PUTORANA PIKAS, AND THE ALTAI PIKA FROM THE ZAPADNYI SAYAN MOUNTAINS (d).

by thin plates of praemaxillae and maxillae. The praemaxillae do not form any evident protrusions to the lateral sides of the palatal opening.

Acoustic signals. In the Putorana northern pika during the call duration the frequency increases and reaches its maximum $3.38-6.01$ kilohertz $(4.32 \pm 0.05$; $\sigma=0.42 ; \mathrm{n}=54)$ after $26.0-58.0$ milliseconds $(37.9 \pm 1.6$; $\sigma=7.9 ; n=24)$. The next future descending branch of the frequency modulation could be expressed at various extend (Fig. 3). The duration of this branch is 23.0-68.0 milliseconds ( $40.3 \pm 2.1 ; \sigma=10.5 ; \mathrm{n}=24)$, and a decimal logarithm of the asymmetry coefficient varies between $0.22-0.92(0.50 \pm 0.03 ; \sigma=0.19 ; n=43)$. This coefficient is the ratio between the frequency diapasons of the ascending and descending branches of the frequency modulation curve (Nikol'skii et al., 1983; Formozov, 1991). The total duration of the signals is 51.0-112.0 milliseconds $(75.4 \pm 1.8 ; \sigma=12.5 ; \mathrm{n}=51)$. The lower limit of the frequency diapason is 2.06-3.33 kilohertz (2.57士 $0.05 ; \sigma=0.33 ; \mathrm{n}=41$ ).

In the Putorana Altai pika the signals are characterized by higher value of the basic frequency: 6.29-9.21 kilohertz ( $7.53 \pm 0.08 ; \sigma=0.58 ; n=48)$. At the same time the modulation could be both arch-shaped (rarely) or having shorter descending branch (Fig. 3). The duration of the frequency modulation is 32.0-58.0 milliseconds $(42.0 \pm 1.5 ; \sigma=6.8 ; n=21)$ for the ascending branch and 34.0-90.0 milliseconds $(63.4 \pm 3.3 ; \sigma=15.0 ; n=21)$ for the descending branch. The value of the decimal logarithm of the asymmetry coefficient varies between 0.06 $0.51(0.31 \pm 0.01 ; \sigma=0.11 ; \mathrm{n}=46)$. The total duration of the signal is $62.4-139.0$ milliseconds $(100.2 \pm 2.7 ; \sigma=$ $18.6 ; n=48)$. The lower limit of the frequency diapason is 2.57-5.69 kilohertz $(3.28 \pm 0.10 ; \sigma=0.60 ; n=34)$.

Earlier Formozov (1991) noted that the shape of the frequency modulation curve is more variable in the Putorana Altai pikas, named by this author as a large race of the Putorana northern pika. For the evaluation of the frequency modulation curve shape the decimal logarithm asymmetry coefficient was used. This supposition is not confirmed by our data. The coefficient of variation (CV) of the logarithm asymmetry coefficient for signals is $35.5 \pm 4.33 \%$ in the Putorana Altai Pika and $38.8 \pm 4.26$ $\%$ in the Putorana northern pika.

\section{Discussion}

Variation. All specimens of the pikas from the Putorana Plateau examined by us by their pelage coloration, body and skull size, shape of the frontoparietal suture and palatal foramen, and the structure of their alarm calls could be unambiguously referred to one of two species (Fig. 4). The only exception is one specimen, ZMMU S-164026, male, collected in the valley of Kutaramakan Lake. Its body and skull size, shape of the palatal foramen and frontoparietal suture fall within range of variation of the Putorana northern pika (its weight $102 \mathrm{~g}$, condylobasal skull length $36.1 \mathrm{~mm}$, zygomatic breadth $20.0 \mathrm{~mm}$ ). However, this specimen shows a red belly which is more characteristic for the Putorana Altai pikas. We cannot exclude the possibility that this specimen has a hybrid origin.

Distribution. In almost all points of the Putorana Plateau where pikas were collected the samples were mixed, containing specimens of both species (Fig. 5). According to the museum specimens, the Putorana Altai pika was recorded also from the lower stream of the Nizhnyaya Tunguska River, a right tributary of the Enisei River, Krasnoyarsk Territory (ZIN 49820, 28865), in the middle stream of the Podkamennaya Tunguska River, a right tributary of the Enisei River, Krasnoyarsk Territory, in the vicinity of the Baikit settlement (ZIN 16851, 20071, 19808, 19809), and in the lower stream of the Angara River, Krasnoyarsk Territory (ZIN 17373, 17419, ISEA M965). The Putorana northern pika is known from the Nizhnyaya Tunguska River (ZIN 48659 and 28866), and between the Nizhnyaya Tunguska and Podkamennaya Tunguska rivers (ZIN 28867).

Previously Naumov (1934), with the reference to Orlov (1930), reported the existence of the northern pika in the Noril'sk Mountains, south of the Taimyr Peninsula. In the cited paper by Orlov (1930: 91) only the following was said concerning the existence of pikas in the Noril'sk Mountains: "the inquiries of the aborigines elucidated that the pikas can be found in the Noril'sk Mountains and on the lower Khatanga [River], but I was not there that summer, and have no actual specimens at hands". In the Noril'sk Mountains we fail to find pikas, dead or alive, or any traces of their activity. But, taking 


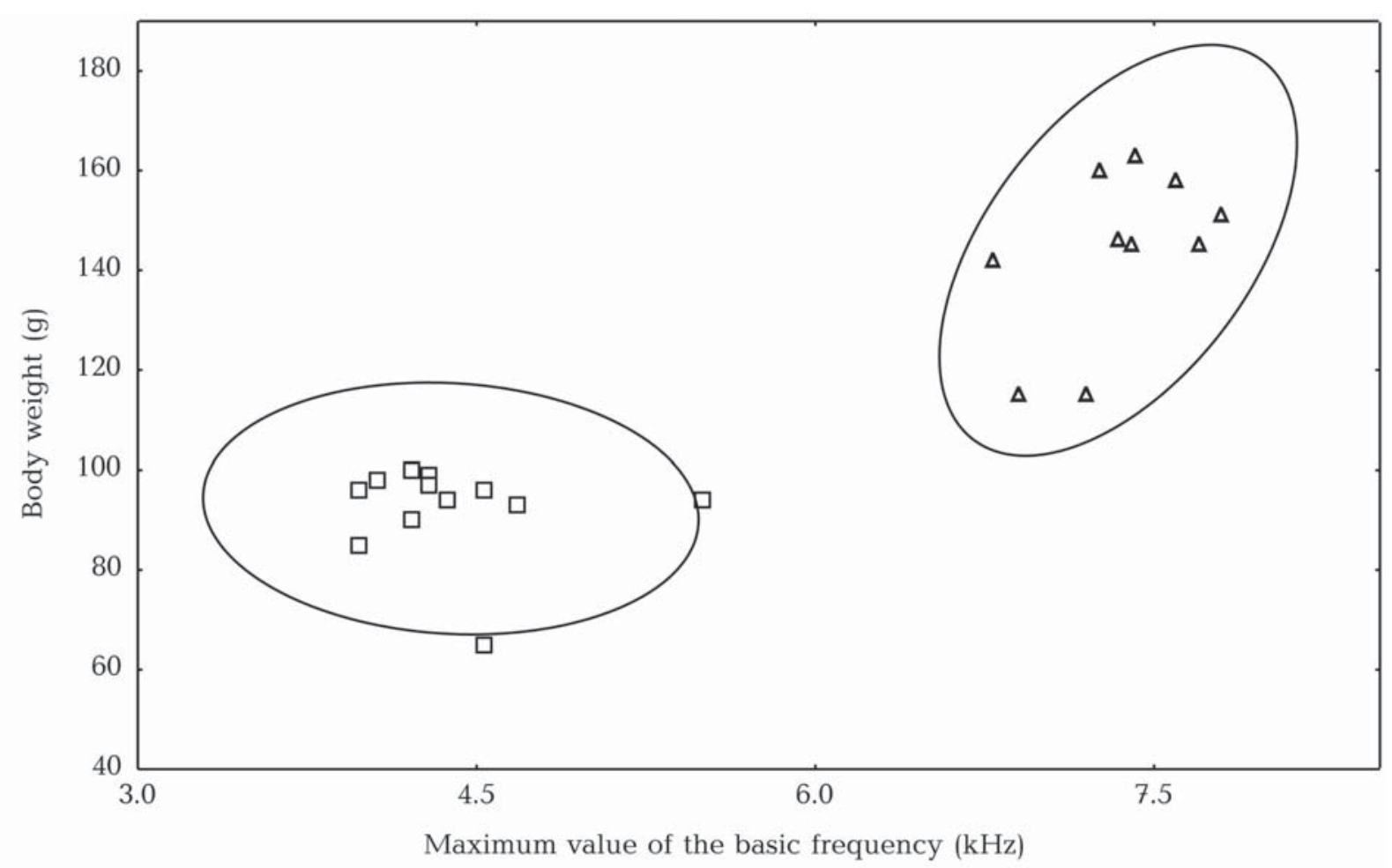

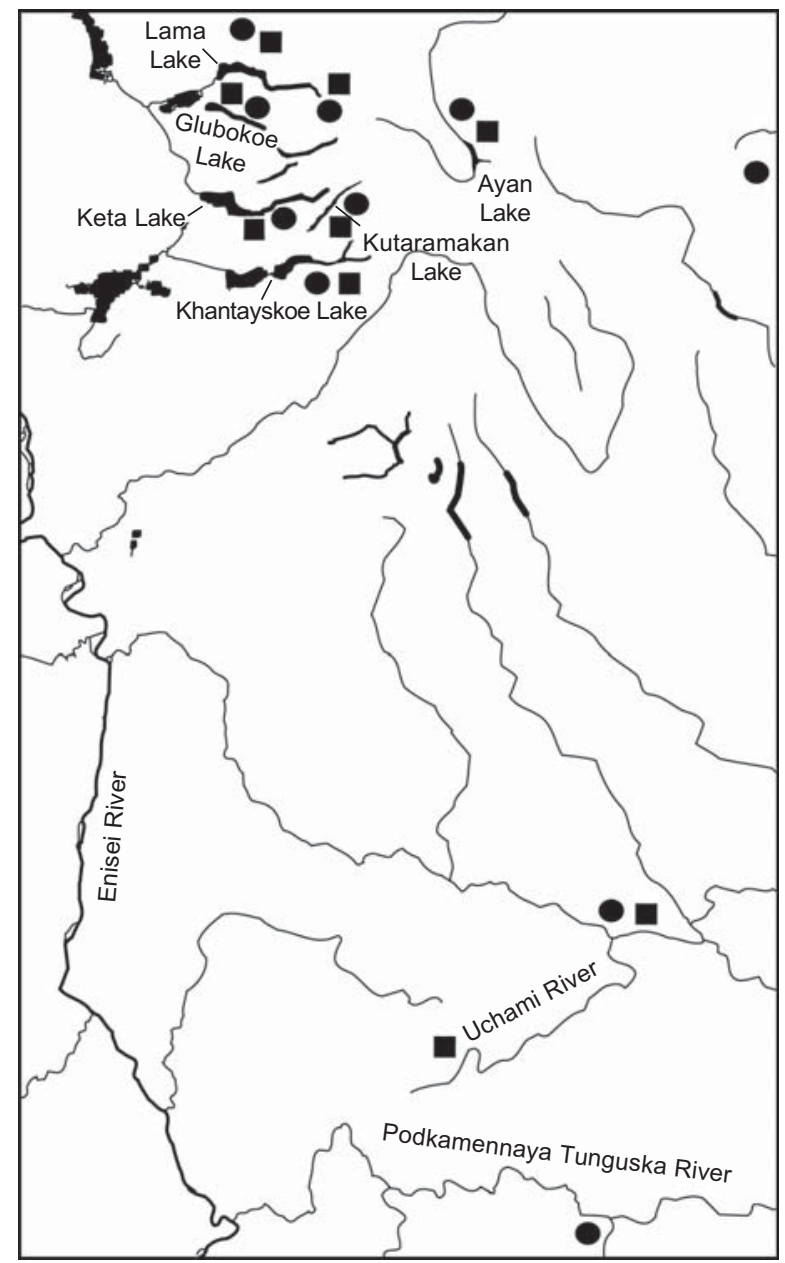

Figure 4. THE DISTRIBUTION OF THE PUTORANA PIKAS IN THE FEATURE SPACE. THE ELLIPSE LIMITS THE 95\% CONFIDENCE INTERVAL.

into account, that only a small portion of the Noril'sk Mountains was investigated, as well as lacking of the museum specimens from that region, we think that the question about the existence there of the pikas should remains open.

Taxonomy. The northern and the Altai pikas are closely related species, forming the one so calledalpinahyperborea species complex (Formozov et al., 1999). By the characters investigated the Putorana northern pika is most similar to the populations inhabited the north-eastern part of the $O$. hyperborea geographic range and the northern Urals. These samples are most close in the structure of the alarm calls (Formozov \& Nikol'skii, 1979; Nikol'skii, 1984; Formozov, 1991) and by the relatively small skull size (Table 2).

The systematic position of the Putorana Altai pika cannot be so precisely settled. On the one side, it has the karyotype identical to that of the specimens from the Altai-Sayany population of $O$. alpina (Formozov et al., 1999). But, on the other side, the alarm calls of the Putorana Altai pika stand out by the peculiar frequency modulation in comparison with the more invariable signals, having symmetrical distribution of the frequencies, which are characteristic for Altai pikas inhabited

Figure 5. THE SCHEME OF THE PUTORANA PIKAS DISTRIBUTION (circles - the Altai pika, quadrates - the northern pika). 
Table 2. Skull measurements (In mm) in some Races of Altai And nORTheRn PikAs.

\begin{tabular}{|c|c|c|c|c|c|c|c|c|}
\hline Sample & $\begin{array}{c}\text { Condylobasal } \\
\text { length }\end{array}$ & $\begin{array}{c}\text { Zygomatic } \\
\text { breadth }\end{array}$ & Sample & $\begin{array}{c}\text { Condylobasal } \\
\text { length }\end{array}$ & $\begin{array}{c}\text { Zygomatic } \\
\text { breadth }\end{array}$ & Sample & $\begin{array}{c}\text { Condylobasal } \\
\text { length }\end{array}$ & $\begin{array}{c}\text { Zygomatic } \\
\text { breadth }\end{array}$ \\
\hline 1 & $44.8-48.7$ & $22.7-24.9$ & 4 & $37.3-42.9$ & $18.3-21.5$ & 7 & $32.3-35.7$ & $18.8-19.7$ \\
\hline 2 & $40.6-47.1$ & $21.3-23.7$ & 5 & $33.5-36.7$ & $17.8-20.1$ & 8 & $34.2-38.4$ & $18.1-20.5$ \\
\hline 3 & $39.5-43.8$ & $20.9-22.8$ & 6 & $32.0-36.8$ & $17.4-19.8$ & 9 & $39.2-42.2$ & $20.3-22.2$ \\
\hline
\end{tabular}

Samples: 1 - O. a. alpina, Western Altai, $\mathrm{n}=9 ; 2-O$. a. nitida, Eastern Altai, Zapadnyi Sayan Mountains, $\mathrm{n}=30 ; 3-$ O. a. nanula, Tuva, $\mathrm{n}=19 ; 4$ - Putorana Altai pika, $\mathrm{n}=22: 5$ - Putorana northern pika, $\mathrm{n}=17 ; 6$-O. h. hyperborea, Chukotka Peninsula, $\mathrm{n}=20 ; 7-O$. h. uralensis, Polar Ural Mountains, $\mathrm{n}=9 ; 8-O$. h. ferruginea, Kamchatka Peninsula, $\mathrm{n}=13 ; 9-O$. h. mantchurica, Bol'shoi Khingan Range, $\mathrm{n}=6$.

Altai-Sayany Mountains (Fig. 3). Differences in the frequency diapason of the ascending and descending modulation branches is more characteristic for the populations of the northern pika (Formozov \& Nikol'skii, 1979; Formozov, 1991).

How much the differences in the structure of alarm calls is correlated with the degree of phylogenetic divergence between the Putorana Altai pika and O. alpina (sensu stricto) is difficult to elucidate. Currently we have no data about distribution of the Altai pika from the lower Angara River basin in the east to the northern slope of the Eastern Sayan Ridge in the west. Preliminary the taxonomic status of the Putorana Altai pika could be treated as a well established geographic subspecies of $O$. alpina.

\section{Conclusions}

Two recently recognized chromosome races of pikas on the Putorana Plateau represent two independent sympatric populations, each of them with a unique set of characters, differentiated at the species level. The differences in the karyotype structure, body and skull dimensions, pelage coloration, alarm calls structure, noted previously for these races (Formozov, 1991; Formozovet al., 1999) are confirmed during our investigation and supplemented by the discovered differences in the skull morphology (frontoparietal suture and palatine foramen).

The most reliable character for distinguishing of the two taxonomic pika races in the Putorana Plateau is the structure of the palatine opening. The next reliable characters include body and skull measurements, but the hiatus between variables is not great, which may cause the wrong determination. The use of the frontoparietal suture character for taxonomic determination is also possible, but requires a comparative skull sample.

ACKNOWLEDGEMENTS. We are grateful to Igor Ya. Pavlinov, curator of the ZMMU theriological collection, Galina I. Baranova, curator of the ZIN theriological collection, and Elena I. Zholnerovskaya, curator of the ISEA theriological collection for the access to the specimens under their care. We thank Vladimir V. Larin, director of the Putorana Zapovednik, for the help in the selection of and arrival at the place of our investigation, Nikolai A. Formozov for valuable comments on the manuscript and Alexander O. Averianov for the translation of this article and valuable comments on the manuscript. Our special thanks are to the persons, who shared with us the field season in the Putorana Plateau, to Vladislav N. Marchenko, Oleg A. Begletsov and Tatyana I. Begletsova.

\section{References}

Naumov N.P. 1934. [Mammals of the Tunguska District] // Trudy polyarnoi Komissii. Vyp.17. P.38-42 [in Russian]. Nikol'skii A.A. 1984. [Acoustic Signals of Mammals in the Evolutionary Process]. Moskva: Nauka. 199 p. [in Russian]. Nikol'skii A.A., Yanina I.Yu., Rutovskaya N.V. \& Formozov N.A. 1983. [The variability of the acoustic signals in bobac and gray marmot (Marmota bobac, M. baibacina, Sciuridae, Rodentia) in the zone of the secondary contact] // Zoologicheskii Zhurnal. T.62. No.8. P.1258-1266 [in Russian].

Ognev S.I. 1940. [Mammals of the USSR and Adjacent Territories, Volume 4. Rodents]. Moskva-Leningrad: Izdatel'stvo AN SSSR. 616 p. [in Russian].

Orlov S.I. 1930. [Northern borders of several small mammals distribution] // Izvestiya Sibirskoi Kraevoi Stantsii Zashchity Rastenii. Vol.4. No.7. P.89-94 [in Russian].

Sokolov V.E., Ivanitskaya E.Yu., Gruzdev V.V. \& Heptner V.G. 1994. [Mammals of Russia and Adjacent Regions: Lagomorphs]. Moskva: Nauka. 272 p. [in Russian].

Formozov N.A. 1991. [Acoustic signalization in pikas (Ochoto$n a$, Lagomorpha): geographic, systematic and ecological aspects]. Avtoreferat Kandidatskoi Dissertatsii. Moskva: Biologicheskii Facultet MGU. 24 p. [in Russian].

Formozov N.A., Lisovskii A.A. \& Baklushinskaya I.Yu. 1999. [Karyological diagnostics of pikas (Ochotona, Lagomorpha) of the Putorana Plateau] // Zoologicheskii Zhurnal. T.78. No.5. P.606-612 [in Russian].

Formozov N.A. \& Nikol'skii A.A. 1979. [Position of the Ural pika in the alpina species group: a bioacoustic analyses] // [Mammals of the Ural Mountains. Information Materials]. Sverdlovsk: Ural'skii Nauchnyi Tsentr AN SSSR. P.80-82 [in Russian].

Formozov N.A., Yakhontov E.L. \& Dmitriev P.P. 1996. [A new form of the Altai pika (O. alpina hoffmanni ssp. n.) from the southern foothills of Khentei Range and likely history of the geographic range of this species] // Byulleten' Moskovskogo Obshchestva Ispytatelei Prirody, OtdelBiologicheskii. Vol.10. No.1. P.28-36 [in Russian].

Khmelevskaya N.V. 1961. [On the biology of the Altai pika] // Zoologicheskii Zhurnal. T.40. No.10. P.1583-1585 [in Russian]. 